\title{
ANALISIS TAFSIRAN ASNAF AL-GHARIMIN DI MALAYSIA
}

\author{
SYARIFAH MD YUSOF \\ RAZIAH MD TAHIR \\ UUM College of Business \\ Universiti Utara Malaysia
}

\begin{abstract}
Abstrak
Islam memperuntukkan zakat sebagai salah satu cara dalam penyelesaian isu hutang. Namun masih terdapat sebilangan individu yang tidak mampu menyelesaikan hutang sehingga diisytiharkan muflis. Masalah keberhutangan dan muflis bukan sahaja menimbulkan kesan yang negatif kepada individu tersebut malah ahli keluarga turut menerima tempiasnya. Persoalannya, adakah semua golongan yang berhutang dan muflis layak untuk mendapatkan zakat bagi mengatasi masalah ini? Sejauh manakah tafsiran asnaf al-gharimin yang sedia ada di Malaysia merangkumi semua golongan yang berhak menerima zakat? Artikel ini bertujuan meneliti tiga perkara utama. Pertama, meneliti isu hutang dan muflis dari perspektif Islam. Kedua, meneliti isu hutang dan muflis di Malaysia. Ketiga, meneliti adakah tafsiran asnaf al-gharimin bagi setiap negeri di Malaysia menyeluruh merangkumi setiap golongan yang berhak menerima zakat. Untuk itu, analisis kandungan berdasarkan data sekunder dijadikan kaedah utama dengan meneliti tafsiran zakat asnaf al-gharimin di setiap negeri di Malaysia. Kajian ini mendapati tafsiran asnaf al-gharimin adalah tidak menyeluruh dan tidak seragam antara negeri-negeri di Malaysia. Oleh itu, penambahbaikan terhadap tafsiran asnaf al-gharimin perlu dilakukan oleh pihak yang berkaitan.
\end{abstract}

Kata kunci: Asnaf al-gharimin, zakat, hutang.

\section{Abstract}

Purpose - The main purpose of this paper is to examine whether the interpretation of asnaf al-gharimin for each state in Malaysia encompassing all those who are eligible to receive zakat.

Design - Content analysis based on secondary data is used as the main method in examining the interpretation of asnaf al-gharimin in every state in Malaysia. 
IJMS 22, Special Issue 81-100 (2015)

Findings - This study found that the interpretation of asnaf al-gharimin are not exhaustive and are not uniform among the states in Malaysia.

Significance - Improvement of the interpretation of asnaf al-gharimin should be done by the relevant authorities.

Keywords: asnaf al-gharimin, zakah, debt.

\section{Pengenalan}

Konsep berzakat sebenarnya dapat menggambarkan kekuatan hubungan manusia dengan Allah SWT dan juga hubungan manusia sesama manusia. Kefarduan hukum berzakat menggambarkan hubungan manusia dengan Allah SWT sebagai satu bentuk ibadah wajib. Hubungan sesama manusia pula digambarkan daripada aspek bantuan kebajikan kepada golongan yang berhak. Golongan yang mempunyai lebihan harta dan berkemampuan diwajibkan mengeluarkan zakat kepada golongan yang kurang berkemampuan. Hal ini dijelaskan melalui firman Allah SWT yang bermaksud:

“Dan pada harta-harta mereka (ada pula bahagian yang mereka tentukan menjadi) hak untuk orang miskin yang meminta dan orang miskin yang menahan diri (daripada meminta)."

\section{(al-Dhariyat, 51:19)}

Kedudukan golongan berada dan golongan kurang berada dalam pola kehidupan masyarakat turut dijelaskan dalam al-Quran seperti mana firman Allah SWT yang bermaksud:

“Dan Allah telah melebihkan sebahagian daripada kamu atau sebahagian yang lain pada rezeki yang dikurniakan-Nya." (al-Nahl, 16:71)

Zakat dan sedekah merupakan satu instrumen jaminan sosial kepada golongan yang memerlukan. Ia digunakan oleh golongan kaya untuk memindahkan sebahagian daripada harta mereka kepada golongan asnaf zakat. Jaminan sosial juga merupakan satu bentuk jaminan yang diberikan oleh pemerintah dalam menyediakan keperluan asas kepada masyarakat. Contoh keperluan asas tersebut seperti tempat tinggal, pakaian, makan dan minum. 
Asnaf zakat pula merujuk kepada mereka yang berhak menerima zakat menurut hukum syarak. Firman Allah SWT yang bermaksud:

\begin{abstract}
"Sesungguhnya sedekah-sedekah itu adalah kepunyaan orang-orang fakir dan miskin dan orang-orang yang menguruskannya, dan orang-orang yang dijinakkan hatinya, dan orang-orang yang berhutang, dan untuk jalan Allah, dan Ibnu Sabil, yang demikian itu sebagai kefarduan yang difardukan Allah, dan Allah amat mengetahui lagi amat bijaksana".
\end{abstract}

(al-Tawbah, 9: 60)

Berdasarkan terjemahan ayat kesembilan surah al-Tawbah, terdapat lapan golongan yang berhak menerima zakat. Mereka adalah golongan fakir ${ }^{1}$, miskin $^{2}$, amil ${ }^{3}$, muallaf ${ }^{4}$, riqab ${ }^{5}$, al-gharimin (orangorang yang berhutang), fisabilillah ${ }^{6}$ dan $i b n u$ sabil ${ }^{7}$. Fokus artikel ini hanya membincangkan tentang asnaf al-gharimin.

Al-gharimun adalah kata jama' dari gharim yang bermaksud tetap. Ia bererti orang yang mempunyai hutang untuk kepentingan bukan maksiat dan tidak mampu untuk menyelesaikannya. Ini bermakna hutang itu tetap pada orang yang berhutang.

Takrif al-gharimin mengikut ulama mazhab Maliki, Syafie dan Hanbali ialah orang yang berhutang sama ada hutang untuk dirinya sendiri atau hutang untuk kemaslahatan masyarakat (al-Qaradawi, 2002). Al-Gharimin merupakan salah satu golongan yang berhak menerima zakat atas dasar memenuhi keperluan dan hajat mereka.

Namun, Hairunnizam, Sanep dan Radiah (2010) menganjurkan pendefinisian semua asnaf bagi memastikan asnaf yang berhak ke atas zakat tidak terabai. Artikel ini bertujuan meneliti semula tafsiran asnaf al-gharimin bagi setiap negeri di Malaysia untuk mengenal pasti sejauh mana tafsirannya menyeluruh dan merangkumi setiap golongan yang berhak menerima zakat.

\title{
Kajian Lepas dan Sorotan Karya
}

Penulisan berkisar isu pengagihan zakat telah banyak dilakukan oleh penulis dan pengkaji terdahulu, antaranya Mujaini Tamrin (2005), Muhammad Syukri Salleh (2006), Sanep Ahmad (2009) dan 
Hairunnizam , Sanep dan Rodiah (2010). Isu ini dibincangkan untuk memastikan pengagihan zakat dapat mencapai matlamat untuk membantu golongan asnaf yang menerima zakat keluar daripada golongan penerima zakat kepada golongan pemberi zakat. Ia juga untuk mencari penyelesaian isu keciciran golongan yang sepatutnya berhak menerima zakat.

Namun, Hairunnizam et al. (2010) mendapati bahawa pengagihan zakat di Malaysia hanya tertumpu kepada tiga asnaf iaitu asnaf fakir, miskin dan asnaf fi sabilillah sedangkan asnaf al-gharimin merupakan antara empat asnaf yang patut diberi perhatian berdasarkan pandangan mazhab Syafi'i. Terdapat banyak lebihan zakat di kebanyakan negeri yang tidak diagihkan kepada asnaf.

Kajian Hairunnizam et al. (2010) menegaskan bahawa definisi setiap asnaf yang lapan menimbulkan masalah kepada amil. Definisi asnaf al-riqab, ibnu sabil dan al-gharimin perlu cuba diperluaskan bagi menyelesaikan permasalahan berkaitan mengikut konteks semasa dan setempat.

Definisi fakir telah diperluaskan maknanya. Fakir tidak hanya merujuk kepada ketidakcukupan harta yang halal dalam memenuhi keperluan asas tempat tingggal, makanan dan pakaian. Definisi baru turut memasukkan perubatan dan pengangkutan sebagai keperluan asas (Suhaili, Nor Azzah \& Nor Aini, 2013). Asnaf riqab pula diperluaskan maknanya kepada orang Islam yang dibelenggu oleh suatu kuasa atau keadaan yang menghalangnya daripada kebebasan seperti penagih dadah dan pelacuran. Tujuan perluasan definisi dibuat untuk memastikan zakat dapat diagihkan secara adil kepada mereka yang memerlukan (Suhaili et al., 2013).

Dalam usaha menangani isu mangsa banjir besar di Kelantan barubaru ini, Hasanah, Siti Fariza dan Irwan (2015) cuba meluaskan definisi al-gharimin kepada mangsa banjir besar yang menanggung hutang setelah kehilangan rumah dan harta benda. Mangsa banjir boleh dikategorikan kepada beberapa asnaf, iaitu asnaf $f i$ sabilillah, asnaf ibnu sabil dan asnaf al-gharimin. Mereka mencadangkan agar pengagihan zakat kepada mangsa banjir dibuat berdasarkan kadar kesusahan yang dihadapi oleh mangsa banjir bagi memastikan semua mangsa yang memerlukan mendapat bantuan yang mencukupi. Oleh itu, artikel ini dipersembahkan bagi meneliti sejauh mana tafsiran asnaf al-gharimin yang sedia ada di Malaysia merangkumi semua golongan yang berhak menerima zakat. 


\title{
Metodologi
}

Kajian melibatkan pengumpulan data sekunder daripada perpustakaan yang terdiri daripada buku, akhbar, jurnal dan laman web 14 buah Jabatan Zakat Negeri di Malaysia. Kajian berbentuk kualitatif ini melibatkan analisis kandungan ke atas dokumendokumen yang dirujuk. Takrifan asnaf al-gharimin bagi semua negeri dianalisis bagi mengeluarkan tema-tema untuk mengenal pasti syarat-syarat kelayakan sebagai asnaf al-gharimin. Seterusnya penelitian dibuat bagi mengkaji sejauh mana kesemua syarat kelayakan tersebut dimasukkan ke dalam takrifan di setiap negeri. Ini bertujuan menentukan takrifan yang diguna pakai oleh setiap negeri adalah bersifat komprehensif.

\section{Hutang dan Muflis dari Perspektif Islam}

Hukum berhutang dalam Islam adalah harus. Keharusan berhutang digambarkan dalam firman Allah SWT sebagaimana terjemahan ayat berikut:

\begin{abstract}
"Wahai orang-orang yang beriman! Apabila kamu melakukan hutang piutang untuk waktu yang ditentukan, hendaklah kamu menuliskannya Dan hendaklah seorang penulis di antara kamu menuliskannya dengan benar. Janganlah penulis menolak untuk menuliskannya sebagaimana Allah telah mengajarkan kepadanya..."
\end{abstract}

(al-Baqarah, 2: 282)

Menurut perspektif Islam, mereka yang berada di dalam kesusahan dan kesempitan hidup diharuskan berhutang. Namun berhutang untuk tujuan berbelanja secara bermewah-mewah dan membazir adalah dilarang. Islam telah meletakkan garis panduan kepada individu agar tidak dibebani hutang yang melampau.

Hutang merupakan satu bentuk tanggungan atau liabiliti. Ia merupakan satu tuntutan kewangan bagi satu tempoh pada masa hadapan. Dalam Islam hutang boleh terhasil daripada pinjaman (alQard) dan jual beli secara bertangguh. Al-Qard menurut pandangan syarak adalah sesuatu yang dipinjamkan atau hutang yang diberikan. Menurut istilah para fuqaha, pinjaman ialah memberi hak milik sesuatu barangan kepada orang lain dengan syarat orang tersebut 
memulangkan semula gantinya tanpa sebarang tambahan (Mustofa al-Khin, Mustafa al-bugha dan Ali al-Syarbaji, 2004; al-Kharufah, 2008). Amalan memberi pinjaman digalakkan dalam Islam kerana ia dapat mengukuhkan lagi hubungan persaudaraan sesama manusia (al-Zuhayli, 1995).

Pembayaran semula hutang boleh dilakukan dalam jangka masa yang dipersetujui oleh kedua-dua pihak tanpa ada apa-apa keuntungan diterima oleh pihak yang memberikan pinjaman (Azlan Khalili, 1995). Akad al-Qard ini boleh menjadi kontrak pembiayaan alternatif bagi memenuhi keperluan dan membantu masyarakat Islam dan semua umat manusia sejagat. Pelaksanaannya mampu mententeramkan jiwa peminjam dan orang yang menawarkan pinjaman (Osman Sabran, 2001).

Hutang yang terhasil menerusi akad jual beli tertangguh banyak diamalkan oleh sistem perbankan Islam. Antaranya ialah pembiayaan kenderaan berdasarkan bay' bithaman ajil dan kad kredit Islam berdasarkan bay' al-'inah dan tawarruq. Pengguna menanggung sejumlah hutang yang telah dinyatakan dalam perjanjian pembiayaan dan perlu melunaskan bayaran mengikut tempoh serta jumlah yang dipersetujui.

Islam memberi penekanan serius kepada soal hutang kerana ia boleh membawa kebencian dan kehinaan kepada seseorang yang gagal melunaskan hutangnya. Rasulullah SAW juga mengajarkan umatnya agar memohon perlindungan daripada belenggu hutang (hadis Sahih Bukhari No 2397). Rasulullah SAW amat menekankan hal ini sehingga diriwayatkan bahawa Baginda enggan menunaikan solat jenazah ke atas mayat seorang sahabat yang belum melangsaikan hutang sebelum kematiannya. Malahan hutang seseorang yang belum dilangsaikan sebelum kematiannya akan terus dipertanggjawabkan pada hari akhirat kelak.

Hutang yang tidak mampu dibayar boleh menyebabkan timbulnya isu muflis. Muflis merujuk kepada entiti yang menghadapi kekurangan kecairan atau aset yang boleh dicairkan untuk membayar hutang apabila sampai tempoh untuk membayar hutang (Awad \& Michael, 2010). Al-Zuhayli (1996) mendefinisikan muflis sebagai orang yang tidak dapat membayar hutang atau yang menanggung hutang jauh lebih besar daripada harta yang ada. Oleh itu, dapat disimpulkan bahawa muflis adalah individu atau pihak yang tidak 
dapat melunaskan hutang apabila telah sampai tempoh (matang) walaupun dia mempunyai harta kerana tanggungan hutangnya adalah jauh lebih besar daripada harta yang dimiliki.

Persoalan muflis dalam kitab fiqh dibincangkan di dalam bab alhajr (sekatan). Bab al-hajr ini membincangkan soal sekatan yang dikenakan ke atas seseorang daripada menguruskan hartanya (al-Zuhayli, 1996). Larangan menguruskan harta itu bertujuan mengelakkan individu berkenaan daripada melakukan kerosakan yang boleh membawa kemudaratan kepada dirinya dan juga pihak lain yang berkaitan. Menurut al-Zuhayli (1996), terdapat dua bentuk sekatan. Pertama, sekatan demi kepentingan individu berkenaan. Kedua, sekatan demi kepentingan orang lain. Sekatan yang pertama dikenakan ke atas orang gila, kanak-kanak, orang yang tidak cukup/lemah akal dan pembazir. Sekatan yang kedua pula ialah ke atas muflis dan penggadai demi menjaga hak pemuitang. Jelas bahawa syarak mengenakan sekatan terhadap pengurusan harta milik muflis demi kebaikan orang lain, iaitu pemberi hutang (al-Zuhayli, 1996).

Perbincangan dalam kitab fiqh menjelaskan bahawa individu muflis boleh dikenakan empat sekatan. Pertama, muflis disekat daripada menderma sebahagian atau semua hartanya. Kedua, muflis dilarang membuat pertukaran harta dan kahwin lebih daripada satu kerana ketidakmampuannya dari segi harta. Ketiga, muflis perlu mengagihagihkan hartanya kepada semua pemiutang setakat mana harta yang dimilikinya. Keempat, pemuitang boleh melarang muflis daripada bermusafir untuk sebarang tujuan untuk mengelakkannya daripada menghilangkan diri dan lari daripada membayar hutang. Hakim dibenarkan mengeluarkan perintah berkurung bagi menyelesaikan kes hutang muflis tersebut.

\section{Isu Hutang dan Muflis di Malaysia}

Hutang telah menjadi satu tabiat dalam masyarakat Malaysia dewasa ini. Tabiat berhutang ini bukan sahaja dilakukan oleh individu yang berpendapatan rendah malahan individu yang berpendapatan tinggi juga berkecenderungan untuk berhutang. Persepsi masyarakat kini melihat pembelian secara tunai merugikan jika dibandingkan dengan pembelian secara hutang. Mereka berpandangan wang yang mereka miliki lebih baik disimpan atau dilaburkan untuk mendapatkan pulangan. 
Menurut Agensi Kaunseling dan Pengurusan Kredit (AKPK), pengurusan kewangan yang teruk menjadi punca tertinggi individu berhutang $(22.8 \%)$, diikuti dengan perbelanjaan perubatan yang tinggi (18.1\%), kegagalan dalam perniagaan (15.3\%) dan kegagalan mengawal penggunaan kad kredit (11.1\%). Punca-punca hutang lain ialah hilang pekerjaan (9.9\%), tidak dinyatakan (6.1\%), lain-lain $(5.7 \%)$, kos hidup tinggi (4.4\%), komitmen kewangan luar jangka $(4.1 \%)$, kematian atau hilang upaya $(1.4 \%)$ dan gagal dalam pelaburan (1.1\%) (Hashnah Abdullah, 27 Februari 2014).

Jadual 1

Punca hutang

\begin{tabular}{lc}
\hline Punca & Peratus \\
\hline Pengurusan kewangan yang teruk & 22.8 \\
Perbelanjaan perubatan yang tinggi & 18.1 \\
Kegagalan dalam perniagaan & 15.3 \\
Kegagalan mengawal penggunaan kad kredit & 11.1 \\
Hilang pekerjaan & 9.9 \\
Tidak dinyatakan & 6.1 \\
Lain-lain & 5.7 \\
Kos hidup tinggi & 4.4 \\
Komitmen kewangan luar jangka & 4.1 \\
Kematian atau hilang upaya & 1.4 \\
Gagal dalam pelaburan & 1.1 \\
\hline Jumlah & 100.0 \\
\hline
\end{tabular}

Sumber: AKPK dipetik dari Utusan Malaysia, 27 Februari 2014.

Jadual 1 menunjukkan bahawa pengurusan kewangan yang teruk dan kegagalan mengawal penggunaan kad kredit merangkumi hampir 34 peratus daripada keseluruhan punca hutang. Ia dilihat berpunca daripada ketidakcekapan individu dalam pengurusan kewangan peribadi. Ini disebabkan oleh tiada perancangan dalam perbelanjaan dan simpanan. Hal ini juga didorong oleh sikap pengguna yang mengutamakan perkara yang tidak penting dalam perbelanjaan harian. Penggunaan kad kredit sebagai cara mudah berbelanja dan penggunaannya secara tidak terancang menyebabkan individu menanggung hutang kad kredit yang tinggi. Ini bermakna 34 peratus individu yang berhutang boleh mengelak daripada berhutang sekiranya mereka berjaya mengurus kewangan peribadi mereka dengan bijak dan berhemah. Walau bagaimanapun, baki kira- 
kira 66 peratus individu berhutang pula tidak dapat mengelakkan diri daripada isu hutang ini atas faktor-faktor di luar kawalan seperti perbelanjaan perubatan yang tinggi, kehilangan pekerjaan, kematian atau hilang upaya dan kegagalan sama ada dalam perniagaan atau pelaburan.

Muflis atau bankrap menggambarkan seseorang yang berada dalam keadaan tidak berupaya hendak menyelesaikan hutang (Kamus Dewan, 2005:1048). Secara purata dilaporkan bahawa seramai 60 orang diisytiharkan muflis pada setiap hari. Mereka yang berumur antara 35-44 tahun merupakan golongan yang paling tinggi terjerumus dalam isu muflis (Zulkifli Jalil, 14 November 2013). Majoriti daripada mereka adalah berbangsa Melayu dengan kira-kira 45 peratus daripada individu muflis.

Meskipun kes muflis tidak meruncing, namun peningkatan jumlahnya pada setiap tahun membimbangkan. Umpamanya, pada tahun 2007, sebanyak 13,238 individu muflis. Dalam tempoh lima tahun berikutnya, jumlah individu muflis yang dicatatkan bagi tahun 2012 ialah 19,575 orang. Jumlah tersebut terus meningkat kepada 21,987 orang pada tahun 2013.

Sewa beli kenderaan dikenal pasti sebagai punca muflis yang paling utama dengan jumlah 30,451 kes (26.14\%). Ini diikuti dengan pinjaman perumahan sebanyak 20,529 kes (17.62\%), pinjaman peribadi berjumlah 18,053 kes $(15.50 \%)$ dan pinjaman perniagaan sebanyak 14,431 kes (12.39\%).

Muflis atau kebankrapan adalah satu pengistiharan oleh mahkamah yang dilakukan oleh pihak bank atau diri penghutang itu sendiri. Had hutang yang membolehkan bank membankrapkan seseorang peminjam adalah RM30,000 dan ke atas (Jabatan Insolvensi, 2013). Tiada had ditetapkan sekiranya penghutang itu sendiri yang mahu memufliskan dirinya sendiri. Seseorang yang berstatus muflis bukanlah penjenayah, sebaliknya ia satu isu berkaitan kegagalan mengurus kewangan dengan berkesan.

Jadual 2 mendedahkan statistik kes yang menjadi punca kebankrapan. Jumlah kes kebankrapan atau muflis di Malaysia bagi tempoh 2007 sehingga Januari 2014 adalah sebanyak 124,457. Menurut Jabatan Insolvensi Malaysia seperti yang dilaporkan dalam akhbar Utusan Malaysia (27 Feb 2014), kategori kebankrapan yang paling tinggi ialah sewa beli kenderaan (26.48\%). Ini kemudian diikuti dengan pinjaman 
perumahan (17.8\%), pinjaman peribadi (15.74\%) dan pinjaman perniagaan (12.28\%). Keempat-empat kategori kebankrapan ini yang merangkumi 72.3 peratus daripada keseluruhan kes kebankrapan adalah pinjaman yang amat lazim kepada isi rumah di Malaysia. Bakinya merangkumi penjamin sosial $(4.99 \%)$, penjamin korporat $(4.16 \%)$, hutang kad kredit $(4.35 \%)$, hutang cukai pendapatan $(0.84 \%)$, biasiswa/pinjaman pelajaran $(0.18 \%)$ dan keberhutangan lain $(13.12 \%)$.

Jadual 2

Jumlah Kes Kebankrapan Mengikut Kategori Keberhutangan dari 2007 hingga Januari 2014

\begin{tabular}{lcc}
\hline \multicolumn{1}{c}{ Kategori Kebankrapan } & Bilangan kes & $\%$ \\
\hline Sewa beli kenderaan & 32,955 & 26.48 \\
Pinjaman perumahan & 22,229 & 17.80 \\
Pinjaman peribadi & 19,590 & 15.74 \\
Pinjaman perniagaan & 15,284 & 12.28 \\
Penjamin sosial & 6,216 & 4.99 \\
Penjamin korporat & 5,181 & 4.16 \\
Hutang kad kredit & 5,412 & 4.35 \\
Hutang cukai pendapatan & 1,046 & 0.84 \\
Biasiswa/pinjaman pelajaran & 219 & 0.18 \\
Keberhutangan lain & 16,325 & 13.12 \\
\hline Jumlah & 124,457 & 100.00 \\
\hline
\end{tabular}

Sumber: Jabatan Insolvensi Malaysiadi petik daripada Utusan Malaysia, 27 Februari 2014.

Muflis adalah satu perkara yang serius. Bank menutup pintu rundingan dan menganggap kebankrapan adalah jalan penyelesaian buat mereka. Individu muflis turut disenarai hitam oleh Jabatan imigresen dan dilarang ke luar negara. Mereka turut disekat daripada memegang jawatan sebagai pengarah syarikat dan tidak boleh bekerja di syarikat yang dimiliki oleh suami, isteri atau saudara mara tanpa kebenaran KPI atau mahkamah. Muflis juga tidak boleh meminjam wang lebih daripada RM1000 tanpa memaklumkan status muflis mereka kepada pemberi pinjaman.

Jabatan Insovensi Malaysia berhak boleh membekukan akaun dan mengambil aset individu muflis yang melebihi RM5,000 kerana aset tersebut terletak hak kepada Ketua Pengarah Insolvensi (KPI). Harta 
kepunyaan individu muflis juga boleh dijual dan hasil yang diperolehi daripada penjualan harta tersebut akan diagihkan kepada pemiutang. Dalam keadaan tertentu, individu muflis boleh diperintahkan untuk membuat bayaran tiga bulanan sebagai sumbangan kepada estet bagi tujuan penyelesaian kepada pemiutang (Jabatan Insolvensi Malaysia, 2014).

Dalam kes muflis ini, tiada pelepasan automatik dipraktiskan di Malaysia. Berdasarkan Akta Kebankrapan 1967, ada tiga cara bagi seseorang yang muflis untuk keluar daripada status bankrap, iaitu pelepasan melalui perintah mahkamah, sijil pelepasan Ketua Pengarah Insolvensi dan pembatalan melalui perintah mahkamah tetapi tertakluk kepada sebarang bantahan daripada pihak pemiutang.

Sebenarnya dalam Islam, ada peruntukan tertentu untuk membantu individu berhutang dan muflis dalam meringankan beban golongan tersebut. Islam menetapkan zakat sebagai salah satu instrumen yang boleh membantu golongan tersebut keluar daripada masalah hutang. Perbincangan seterusnya adalah tentang syarat-syarat kelayakan orang yang berhutang dan muflis untuk menerima zakat di bawah asnaf al-gharimin.

\section{Tafsiran Asnaf al-gharimin di Malaysia}

Tafsiran asnaf al-gharimin di Malaysia dibuat oleh Jabatan Zakat setiap negeri. Setiap negeri pula mempunyai tafsiran tersendiri mengenai asnaf al-gharimin. Tafsiran tersebut disenaraikan Jadual 3.

Jadual 3

Tafsiran Asnaf al-Gharimin Mengikut Negeri di Malaysia

\begin{tabular}{l}
\hline Bil. Pusat Urus Zakat/ \\
Lembaga Zakat/ \\
Jabatan Zakat/ \\
Baitulmal
\end{tabular}

Kedah

Orang yang berhutang untuk kepentingan bukan maksiat dan tidak sanggup membayarnya. Adapun orang yang berhutang untuk memelihara persatuan umat Islam dibayar hutangnya itu dengan zakat, walaupun ia mampu membayarnya.

(sambungan) 


\begin{tabular}{|c|c|c|}
\hline Bil. & $\begin{array}{c}\text { Pusat Urus Zakat/ } \\
\text { Lembaga Zakat/ } \\
\text { Jabatan Zakat/ } \\
\text { Baitulmal }\end{array}$ & Tafsiran Asnaf al-gharimin \\
\hline & Pulau Pinang & $\begin{array}{l}\text { Kesusahan berat/hutang, rawatan kronik/dialisis, } \\
\text { yuran STAM/STPM, pengurusan jenazah tak } \\
\text { berwaris, baik pulih pondok pengajian dan } \\
\text { sumbangan kepada institusi khas (Sek. Terencat } \\
\text { Akal/ Anak Yatim/ Buta/ Pekak). }\end{array}$ \\
\hline & Perak & $\begin{array}{l}\text { Bantuan menyelesaikan hutang pendaftaran di } \\
\text { pusat pengajian tinggi dalam negeri, hutang } \\
\text { tambang tiket kapal terbang dan sebagainya serta } \\
\text { bayaran balik pinjaman berjadual kepada Kerajaan } \\
\text { Negeri. Pemohon hendaklah mengemukakan } \\
\text { bukti keterhutangan dan menunjukkanikhtiar dan } \\
\text { usaha yang telah dibuat untuk menyelesaikannya } \\
\text { sebelum membuat permohonan tersebut. Hutang } \\
\text { untuk perkara yang bukan untuk kepentingan } \\
\text { syarie atau keperluan syarie atau keperluan untuk } \\
\text { bermewah akan ditolak. }\end{array}$ \\
\hline
\end{tabular}

Selangor Hutang kerana keperluan hidup, hutang persatuan kerana permasalahan ummah, hutang rawatan mesin dialisis, hutang perubatan dan pengurusan jenazah tanpa waris.

Wilayah Orang yang menanggung hutang untuk Persekutuan tujuan yang bukan maksiat dan tidak mampu menyelesaikannya.

Negeri Sembilan Golongan yang berhutang untuk memenuhi keperluan asas bagi kemaslahatan diri, keluarga, tanggungannya atau masyarakat Islam yang memerlukan penyelesaian segera dan dibenarkan oleh hukum syarak.

Melaka Orang yang menanggung hutang yang dibenarkan oleh syarak seperti hutang untuk maslahah orang ramai tetapi tidak mampu membayar hutang tersebut.

Johor Golongan yang berhutang untuk memenuhi keperluan asas diri, keluarga, tanggungannya atau masyarakat dan memerlukan penyelesaian segera selaras dengan hukum syarak.

Pahang Golongan yang berhutang untuk memenuhi keperluan asas diri, keluarga, tanggungannya atau masyarakat dan memerlukan penyelesaian segera yang dibenarkan syarak. 


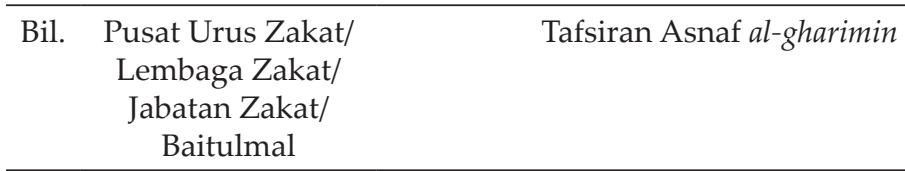

\begin{tabular}{ll}
\hline Terengganu & Golongan yang berhutang untuk memenuhi \\
& keperluan asas bagi kemaslahatan diri, keluarga, \\
& tanggungannya atau masyarakat Islam yang \\
& memerlukan penyelesaian segera dan dibenarkan \\
& oleh hukum syarak.
\end{tabular}

Kelantan Orang-orang berhutang untuk faedah awam seperti untuk menghapuskan persengketaan dua pihak dan sebagainya. Bagi individu yang berhutang untuk tujuan peribadi, mereka hanya boleh dimasukkan ke dalam asnaf ini dengan syarat beliau mestilah tidak memiliki harta dalam kadar yang mencukupi (haddul kifayah).

Sabah Orang yang berhutang untuk tujuan bukan maksiat, bantuan perubatan dan rawatan, pengurusan jenazah, bantuan baik pulih surau dan masjid, bantuan kepada Sekolah Agama Rakyat, Pertubuhan Bukan Kerajaan dan Tajaan program Islamik.

Sarawak Orang yang terpaksa berhutang disebabkan keperluan mendesak yang tidak berlebih-lebihan bagi diri dan masyarakat Islam yang bukan kerana maksiat (nafsu).

Perlis Orang yang berhutang untuk memenuhi keperluan asas bagi kemaslahatan diri, keluarga, tanggungannya atau masyarakat Islam yang memerlukan penyelesaian segera dan dibenarkan oleh hukum syarak.

Sumber: Diubah suai berdasarkan maklumat yang diakses dari laman web Pusat Zakat negeri-negeri yang berkenaan.

Merujuk kepada Jadual 3, individu yang menanggung tunggakan hutang tergolong dalam asnaf al-gharimin. Namun, tidak semua golongan berhutang dikategorikan dalam takrifan al-gharimin. Berdasarkan takrif al-gharimin oleh lembaga-lembaga zakat negeri di Malaysia, syarat-syarat terhadap al-gharimin yang layak mendapat bantuan adalah seperti berikut:

(1) Tiada harta atau sumber kewangan yang melebihi keperluan asasi 
Individu yang berhutang mestilah tidak memiliki harta dalam kadar yang mencukupi (had kifayah). Had kifayah bermaksud garis kecukupan minimum bagi keperluan asasi seseorang dan tanggungannya berdasarkan kos sara hidup masa kini. Keperluan asasi yang diambil kira dalam menentukan had kifayah merangkumi beberapa aspek. Misalnya, Lembaga Zakat Selangor mengambil kira enam aspek, iaitu perlindungan, makanan, pakaian, perubatan, pendidikan dan pengangkutan dalam menentukan fardhu kifayah.

\title{
Tujuan hutang yang dibenarkan syarak
}

Al-Qaradawi (2002) menjelaskan bahawa tujuan berhutang mestilah perkara yang harus atau bertujuan melaksanakan ketaatan kepada Allah. Hutang untuk tujuan maksiat tidak tergolong dalam algharimin. Contohnya seseorang berhutang untuk tujuan berjudi, membeli nombor ekor tidak layak untuk menerima zakat bagi membayar hutangnya. Begitu juga dengan berbelanja secara berlebihlebihan, membazir dan bermewah-mewah (al-Qaradawi, 2002). Ini kerana Allah melarang perbuatan berlebih-lebihan sebagaimana firman Allah dalam al-Quran yang bermaksud:

\begin{abstract}
"Wahai anak-anak Adam! Pakailah pakaian kamu yang indah berhias pada tiap-tiap kali kamu ke tempat ibadat (atau mengerjakan sembahyang) dan makanlah serta minumlah dan jangan pula kamu melampau; sesungguhnya Allah tidak suka akan orang-orang yang melampaui batas."
\end{abstract}

\section{(al-A'raf, 7:31)}

Dalam konteks muflis, tujuan hutang yang menjadi punca kepada kemuflisannnya harus dikenal pasti terlebih dahulu. Muflis yang beragama Islam layak menerima bantuan zakat sekiranya hutang yang dibuat di dalam perkara-perkara yang halal dan harus atau perkara syar'i. Lembaga zakat di Malaysia menyenaraikan tujuantujuan berhutang bagi asnaf al-gharimin yang berhutang untuk kemaslahatan diri sendiri seperti berikut:

(i) Memenuhi keperluan perkara asasi atau darurat bagi diri, keluarga, tanggungan.

a. Pendidikan - kos pengajian universiti, yuran STAM, STPM.

b. Bayaran balik pinjaman pendidikan berjadual kepada kerajaan negeri. 
(ii) Kos rawatan penyakit kritikal - rawatan penyakit kronik, dialisis darah.

Tujuan berhutang bagi asnaf gharimin yang berhutang untuk kepentingan orang lain menurut Lembaga zakat negeri di Malaysia adalah seperti berikut:

(i) Memenuhi keperluan perkara asasi atau darurat bagi masyarakat.

(ii) Baik pulih pondok pengajian dan sumbangan kepada institusi khas (sekolah terencat akal/ anak yatim/ buta/ pekak).

(iii) Bantuan baik pulih surau dan masjid, bantuan kepada sekolah agama rakyat, pertubuhan bukan kerajaan dan tajaan program islamik.

(iv) Hutang persatuan kerana permasalahan ummah.

(v) Berhutang untuk faedah awam seperti menghapuskan persengketaan dua pihak.

(vi) Pengurusan jenazah tanpa waris.

Al-gharimin yang berhutang untuk menyelesaikan permasalahan asasi seperti kesihatan, pelajaran di peringkat rendah dan menengah, makanan, tempat perlindungan sementara dan segala hutang untuk meninggikan martabat agama dibantu terus daripada peruntukan asnaf al-gharimin tanpa melihat kepada jumlah yang ditanggung. Ini bermakna, peminjam Pinjaman Tabung Pendidikan Tinggi Nasional (PTPTN) yang tidak mempunyai sumber dana bagi menjelaskan pinjaman pelajaran boleh tergolong sebagai al-gharimin .

Merujuk kepada takrifan al-gharimin oleh lembaga zakat di Malaysia, tiada satu pun negeri yang melayakkan al-gharimin berhutang untuk perkara yang bukan untuk kepentingan syarie menerima zakat. Individu yang berhutang untuk tujuan bermewah-mewah juga terkeluar daripada asnaf al-gharimin yang berhak menerima zakat.

Tidak berlebih-lebihan dalam memenuhi keperluan diri dan masyarakat

Orang yang berhutang tidak boleh berlebih-lebihan. Umpamanya dalam pengurusan jenazah, hutang untuk perbelanjaan batu nisan yang cantik dan membina binaan di kubur adalah termasuk dalam hutang yang membazir dan berlebih-lebihan. Ruang lingkup hutang yang 'berlebih-lebihan' juga boleh bergantung kepada uruf setempat. 
(4) Wujud keperluan menyelesaikan hutang dengan segera

Bagi individu muflis, sememangnya mereka berada dalam keadaan terdesak untuk menyelesaikan hutang mereka dengan segera memandangkan tempoh membayar hutang telah sampai, malahan bayarannya tertunggak. Walau bagaimanapun, tujuan mereka berhutang juga perlu dikenal pasti terlebih dahulu dalam menentukan kadar yang sepatutnya boleh diambil kira sebagai kategori asnaf algharimin.

\section{Mendatangkan kemudharatan terhadap diri dan keluarga}

Individu yang berhutang berhadapan dengan tekanan hidup. Umpamanya orang-orang yang berhutang dengan 'ah long' yang merupakan skim pinjaman tidak berlesen berhadapan dengan tindakan kejam daripada pihak tersebut. Terdapat kes peras ugut dan bunuh yang melibatkan pinjaman 'ah long' (Ram al-Jaffri Saad, 20 Disember 2013).

(6) Orang yang berhutang telah berusaha untuk membayar hutangnya

Individu yang berhutang haruslah menunjukkan bahawa mereka telah berikhtiar dan berusaha untuk menyelesaikan hutang sebelum membuat permohonan tersebut.

Ringkasnya, tafsiran asnaf al-gharimin terhadap definisi yang diberi oleh kesemua negeri mendapati wujud enam syarat yang perlu dipenuhi oleh seseorang untuk melayakkannya menerima zakat di bawah asnaf al-gharimin. Namun, tidak kesemua negeri memasukkan keenam-enam syarat itu dalam takrifan asnaf al-gharimin. Oleh itu, pendefinisian semula dicadangkan bagi negeri yang menggunakan definisi yang terlalu ringkas agar definisi baharu merangkumi keenamenam syarat berkenaan. Definisi yang lengkap dan menyeluruh akan memudahkan amil mengenal pasti asnaf al-gharimin.

Kajian menyimpulkan bahawa tafsiran asnaf al-gharimin di Malaysia boleh dibahagikan kepada dua bahagian. Pertama, tafsiran secara umum. Tafsiran ini tidak memasukkan contoh dan tujuan berhutang. Terdapat sepuluh negeri dalam kategori pertama ini iaitu Wilayah Persekutuan, Melaka, Pahang, Terengganu, Johor, Kelantan, Kedah, Perlis, Negeri Sembilan dan Sarawak. Kedua, tafsiran secara khusus. Tafsiran ini menyatakan dengan jelas syarat-syarat asnaf al-gharimin 
beserta contoh dan tujuan berhutang. Hanya empat negeri sahaja yang menggunakan tafsiran secara khusus ini, iaitu Pulau Pinang, Perak, Selangor dan Sabah. Keempat-empat negeri berkenaan menyenaraikan secara khusus contoh yang hampir sama bagi golongan yang berhak menerima zakat di bawah asnaf al-gharimin. Namun begitu, tiada satu negeri pun yang menyebut secara khusus berkenaan mangsa banjir sebagai pihak yang termasuk dalam asnaf al-gharimin. Hasanah Abd. Khafidz et al. (2015) menjelaskan bahawa Mufti Wilayah Persekutuan berpandangan mangsa banjir boleh dikategorikan sebagai asnaf al-gharimin .

\section{Kesimpulan}

Secara keseluruhannya individu berhutang dan muflis layak menerima zakat bagi menyelesaikan masalah keberhutangan mereka. Walau bagaimanapun, ia tertakluk kepada enam syarat. Artikel ini juga mendapati tafsiran asnaf al-gharimin bagi setiap negeri tidak seragam dan tidak menyeluruh. Hal ini menimbulkan masalah kepada amil dalam mengenal pasti mereka yang layak menerima zakat. Masyarakat pula tidak jelas tentang siapakah yang layak untuk menerima zakat asnaf al-gharimin. Oleh itu, artikel ini mencadangkan tafsiran tersebut dibuat penambahbaikan dengan memasukkan keenam-enam syarat. Tafsiran itu juga perlu menyatakan secara khusus berkenaan siapakah yang sebenarnya termasuk dalam asnaf zakat al-gharimin dengan memberikan contoh yang jelas. Hal ini akan memudahkan amil mengenal pasti asnaf al-gharimin yang benar-benar layak. Masyarakat setempat juga dapat membantu pihak jabatan zakat dengan menyalurkan maklumat individu yang layak menerima bantuan zakat asnaf al-gharimin.

Walau bagaimanapun artikel ini hanya menilai tafsiran asnaf algharimin berdasarkan maklumat yang diperoleh dari laman web jabatan zakat di setiap negeri di Malaysia. Kajian terperinci boleh dilakukan melalui temu bual dengan pegawai jabatan zakat dan kumpulan pakar dalam bidang berkaitan zakat untuk tafsiran yang lebih menyeluruh dan teratur serta seragam yang dapat digunapakai oleh semua negeri di Malaysia.

\section{Nota Akhir}

1 Fakir adalah orang yang tidak berharta serta tidak mempunyai pekerjaan sama sekali atau orang yang mempunyai harta dan pekerjaan tetapi tidak dapat menampung keperluan hariannya. Contoh, keperluannya sehari ialah RM10.00 tetapi dia hanya ada RM2.00 (http://zakat.com.my). 
2 Miskin adalah orang yang mempunyai harta tetapi tidak mencukupi keperluan hariannya.Contoh, keperluannya sehari ialah RM10.00 tetapi dia hanya ada RM7.00 (http://zakat.com.my).

3 Amil adalah orang/pekerja yang ditugaskan oleh pemerintah mengutip/ mengagih zakat (http://zakat.com.my).

4 Muallaf adalah saudara baru memeluk Islam (http://zakat.com.my).

5 Riqab adalah hamba yang menebus dirinya secara ansuran (http://zakat. com.my).

6 Fi sabilillah adalah orang yang berjuang di jalan Allah (http://zakat.com. my).

7 Ibnu Sabil adalah musafir yang terputus bekalannya semasa di perantauan (http://zakat.com.my).

\section{Rujukan}

Awad A. \& Michael. R. E., (2010). Iflas and Chapter 11: Classical islamic law and modern bankruptcy, 44 Int'l Law, 975-1000.

Ala al-Din al-Kharufah. (2008). Aqad Hutang Puitang Menurut Syariat Islam dan Undang-Undang Sivil. Selangor: Crescent News.

al-Qaradawi, Yusuf. (2002). Hukum zakat (Salman Harun, Didin Hafidhuddin \& Hasanuddin, Pentj.). Bogor, Indonesia: Pustaka Litera AntarNusa.

al-Zuhayli, Wahbah. (1995). Figh dan Perundangan Islam, Jilid IV, (Md Akhir Haji Yaacob, Pentj.). Kuala Lumpur: Dewan Bahasa dan Pustaka.

al-Zuhayli, Wahbah. (1996). Figh Perundangan Islam, Jil 5, (Ahmad Shahbari Salamon, Pentj.) Kuala Lumpur: Dewan Bahawa dan Pustaka.

Azlan Khalili Shamsuddin. (1995). Riba: Alternatifnya dalam sistem bank islam. Kuala Lumpur: Dewan Bahasa dan Pustaka.

Hairunnizam Wahid, Sanep Ahmad, \& Radiah Abdul Kader. (2010). Pengagihan zakat oleh institusi zakat kepada lapan asnaf: Kajian di Malaysia. Jurnal Pengurusan JAWHAR, 4 (1), 141-170.

Hasanah Abd. Khafidz, Siti Fariza Muhammad Fisal, \& Irwan Mohd Subri. (2015). Penggunaan kaedah figh al-darurah tuqaddar biqadariha dalam agihan zakat untuk mangsa banjir. eProsiding Seminar Fiqh Semasa (SeFis) 2015, 1-6. http://usulifaqihrc.com/ eprosiding/wpcontent/uploads/2015/06/HasanahAbdKhafidz.pdf

Hashnah Abdullah. (27 Februari 2014). Peluang kedua individu muflis, Mega focus. Utusan Malaysia, hlm. 2-3.

Jabatan Insolvensi Malaysia (Mdi). (2011). Ceramah keutuhan bheuu, kebankrapan di kalangan penjawat awam. Dicapai daripada http://www.bheuu.gov.my/intranet/ pdf/ceramah keutuhan/februari\%202011kebankrapan\%20dikalangan\%20 penjawat\%20awam.pdf. 
Jabatan Zakat Negeri Kedah Darul Aman. (2014, 15 Mei). Dicapai daripada http://www.zakatkedah.com

Majlis Agama Islam dan Adat Melayu Perak. (2014, 15 Mei). Dicapai daripada http://www.maiamp.gov.my/

Majlis Agama Islam dan Adat Melayu Terengganu. (2014, 15 Mei). Dicapai daripada http://maidam.terengganu.gov.my/

Majlis Agama Islam Johor. (2014, 15 Mei). Dicapai daripada http:// www.maij.gov.my/

Majlis Agama Islam Kelantan (MAIK). (2014, 15 Mei). Dicapai daripada http://www.e-maik.my

Majlis Agama Islam Melaka. (2014, 15 Mei). Dicapai daripada http:// www.maim.gov.my/

Majlis Agama Islam dan Adat Istiadat Melayu Perlis. (2014, 15 Mei). Dicapai daripada http://www.maips.gov.my

Muhammad Ayyub. (2007). Understanding islamic finance. England: John Wiley \& Sons.

Muhammad Syukri Salleh. (2006). Lokalisasi pengagihan zakat: Satu cadangan teoriti. dalam (Hailani Muji Tahir dan Abdul Ghafar, Penyt). Zakat: Pensyariatan, Perekonomian \& Perundangan. Bangi: Penerbit Universiti Kebangsaan Malaysia.

Mujaini Tarimin. (2005). Golongan penerima zakat, agihan dana zakat secara lebih berkesan. Shah Alam: Penerbit UiTM.

Mustofa al-Khin, Mustafa al-Bugha \& Ali al-Syarbaji. (2004). Fiqh Mazhab Syafie (Ust. Solehan Ayub Pentj.). Shah Alam: Pustaka Salam Sdn. Bhd.

Osman Sabran. (2001). Urusniaga al-Qard al-Hasan dalam mekanisme pembiayaan tanpa riba. Skudai: Penerbit Universiti Teknologi Malaysia.

Portal Rasmi Jabatan Insolvensi Malaysia. (2014, 23 Mac). Dicapai daripada http://www.insolvensi.gov.my/ms/about-us/corebusiness/ core-business/personal-bankruptcy

Pusat Kutipan Zakat Pahang. (2014, 15 Mei). Dicapai daripada http:// www.zakatpahang.my/

Pusat Pungutan Zakat Wilayah Persekutuan. (2014, 15 Mei). Dicapai daripada http://www.zakat.com.my/

Pusat Urus Zakat Pulau Pinang. (2014, 15 Mei). Dicapai daripada http://www.zakatpenang.com/

Pusat Zakat Melaka. (2014, 15 Mei). Dicapai daripada http://www. izakat.com/

Pusat Zakat Negeri Sembilan. (2014, 15 Mei). Dicapai daripada http:// zakatns.com.my/

Ram al-Jaffri Saad. (2013, 20 Disember). Dana zakat Melayu muflis. Utusan Malaysia. 
IJMS 22, Special Issue 81-100 (2015)

Razali Othman \& Rohayu Abdul Ghani. (2011). Sektor ijtimai: Ke arah pemantapan sosio-ekonomi ummah, Jurnal Pengurusan JAWHAR, 5 (1), 99-130.

Sanep Ahmad. (2009). Agihan zakat merentasi asnaf: Ke arah memperkasa institusi zakat, Prosiding Persidangan Kebangsaan Ekonomi Malaysia (PERKEM), 2, 62-74.

Suhaili Sarif, Nor Azzah Kamri, \& Nor Aini Ali. (2013). The shifts in zakah management practices in Malaysia: What has actually been happening? Jurnal Syariah, 21(1), 1-20.

Tabung Baitulmal Sarawak. (2014, 15 Mei). Dicapai daripada http:// www.tabung-baitulmal-sarawak.org.my/

Zakat Sabah. (2014, 15 Mei). Dicapai daripada http://www.zakat. sabah.gov.my/ 